\author{
Ana Margarida Ramos \\ CIDTFF - University of Aveiro (Portugal) \\ anamargarida@ua.pt
}

\title{
From occupation to independence: contemporary East Timorese history and identity in Portuguese picturebooks
}

\section{Summary}

In Portugal, the suffering and struggle of the East Timorese people for independence started a social movement of solidarity with strong repercussions in the arts, namely music and literature. Children's Literature depicted the theme of this period of oppression in East Timor, as well as the recognition of its independence and its right to freedom, in a picturebook selected for the White Ravens List in 2003 called East Timor - Island of the Rising Sun (2001), by João Pedro Mésseder and André Letria. This unusual picturebook, characterised by a very simple and sparse, almost poetic, text combined with large-format pictures, depicts this chapter of the contemporary history of East Timor in very specific way, resembling fairy tales or legends. The text and images are combined in order to promote symbolic readings, suggesting a magical/mystical environment that impresses readers. More than a decade later, recent struggles and stories from East Timor are still present in Portuguese picturebooks such as Lya/Lia (2014), by Margarida Botelho. The social change, path to democracy and educational development, as well as daily life and children's pastimes are now the centre of a narrative that establishes the similarities and differences between modern-day Portugal and East Timor. Our aim is to analyse both the political and ideological perspectives present in these picturebooks aimed at very young readers, offering a broad vision of different realities and contexts, even when they deal with war, death and suffering, as was the case of the East Timorese fight for independence.

Key words: picturebooks, ideology, political, contemporary history, East Timor

Słowa klucze: książki obrazkowe, ideologia, polityka, historia współczesna, Timor Wschodni

\section{Introduction. East Timor: a special case in contemporary Portuguese History}

When on $25^{\text {th }}$ April, 1974, the popular military revolution in Portugal ended almost five decades of dictatorship, few events were able to unite a country around a cause as much as the struggle in East Timor. East Timor makes up half of a small island in South West Asia and was part of the Portuguese Colonial Empire for almost 500 years, with a brief period of occupation by the Japanese during World War II.

A result of the Carnation Revolution in 1974 and the process of democratisation of Portugal and its political organisation, was the decolonisation and independence of Portuguese Speaking African countries (ex-colonies or provinces overseas such as Angola, Mozambique, Cape Verde, São Tomé and Príncipe and Guinea) as well as East Timor in 1975. 
East Timor claimed its independence on $28^{\text {th }}$ November, 1975 but was almost immediately invaded by the Indonesian military on $7^{\text {th }}$ December of that same year. Although this occupation was never officially recognized by the UN, which maintained Portugal as the administrative power in East Timor, it lasted until $30^{\text {th }}$ August, 1999, when a referendum, which drew high participation, voted for independence of the territory.

During the 24 years of Indonesian occupation, marked by massacres and genocide which exterminated over a quarter of the population, the Portuguese people were not always well informed or particularly attentive to the conflict occurring over 14,000 kilometres away. Despite the continued effort of small groups and sectors of Portuguese society, namely youth movements, it was only towards the end of the 1980s that the media took hold of the issue and started leaving its mark on Portuguese public opinion.

Before the visit of Pope John Paul II to East Timor in 1989, there were various student and resistant demonstrations which were harshly repressed and which drew international attention. However, the most significant event took place on $12^{\text {th }}$ November 1991, when Indonesian troops attacked a group of Timorese people gathered at the Santa Cruz Cemetery to pay their last homage to a young man who had been killed by Indonesian soldiers. This massacre resulted in over 250 deaths and was recorded on film by the British journalist Max Stahl (previously known as Christopher Wenner) and the footage, which slipped through tight Indonesian control, made headlines all over the world. Its impact, particularly in Portugal, was colossal. Nobody was indifferent to the suffering of a people who were slaughtered in a cemetery while they prayed in Portuguese. Portugal immediately took notice of the strife of the Timorese cause, which it refused to abandon until East Timor's independence and to which it still has strong ties.

Important to note was the referendum of $30^{\text {th }}$ August, 1999, which was followed by a wave of violence from pro-Indonesian militia groups, resulting in the destruction of all the existing infrastructures and the death of supporters for independence, the burning of all their belongings and the creation of thousands of refugees in the aftermath of the victory of the independence movement. The country lived days of terror after which UN military forces were sent in to try and restore peace and an interim government until East Timor's full independence on $20^{\text {th }}$ May, 2002.

Portuguese support for the Timorese cause came in the form of multiple demonstrations and actions which brought together many sectors of society, including political parties. From a cultural point of view, East Timor gave rise to songs, transformed into anthems, and a wealth of publications, particularly from the 1990s onwards. The interventional nature of many of these texts, calling out to the resistance movement as well as to Portuguese solidarity, was extended to poetry and contemporary narratives, and was present in the works of such renowned authors as Sophia de Mello Breyner, Manuel Alegre, Teresa Rita Lopes and João Pedro Mésseder, as well as in books written by multiple authors such as Um Grito por Timor (A Cry for East Timor, 1999) and Uma Rosa para Timor (A Rose for East Timor, 2005). 
The objective of this paper is to analyse two Portuguese children's picturebooks which deal with the issue of East Timor, giving readers information not only about its recent history and suffering on its road to independence, but also paving ways of hope, reconstruction and development, demonstrating the features which help create/reinforce the identity of the country and underpinned by an explicitly ideological connotation (Stephens 1992; Meek 2001). At the same time, they bring the Portuguese reader closer to a geographically distant setting, bound together by a common history, language and by the ideals of freedom and independence, highlighting a particular set of values and contributing to the construction of a national identity.

\section{Representations of East Timor in children's literature}

The construction of a national identity through children's literature and literature for young adults

The issue of national identity and its construction lies mainly in the sharing of common factors such as memory, culture and language, often based on the principle of "us" and "them", where "the other" is perceived as "different":

A national identity involves a widely shared memory of a common past for people who have never seen or talked to one another in the flesh. This sense of belonging depends as much on forgetting as on remembering, the past being reconstructed as trajectory to the national present in order to guarantee a common future. (Agnew 1998: 215)

Identity, characterised as a "shifting, slithering concept" (Meek 2001: viii), is also constructed around more or less idealised representations of ancestral roots and values, often perceived as "original" or even "lost" to progress, development and globalisation. According to Meek "Identity also includes notions of the self that imply our historicalcultural being" (Meek 2001: viii). Children's books, and in particular picturebooks due to the inclusion of illustrations in their communicative intent, have the ability to reinforce, through words and images, a series of identity markers which should be preserved and disseminated. Carol Fox states that "literature is a major medium for nation-defining" (Fox 2001: 43), and maintains that national identity can be defined "as whatever cultural characteristics a society (or nation) feels its members share that distinguish it from other groups" (Fox 2001: 44).

Studies carried out in other contexts, some of which are geographically close to East Timor, such as Malaysia (Desai 2006), highlight the need to reflect upon the way in which children's literature represents and promotes national identity, particularly in multicultural and multilingual societies.

There are some stable elements in Timorese identity, such as the crocodile, which evokes strong symbolic and mythical feelings and is strongly associated with the legend of the country's origin, emulating the shape of the country itself as well as an ancestor; the 
mountains, which are sacred places and symbols of safe havens from enemies and which protect the souls of their ancestors; the sunrise, linked to the geography of the country, present in the name of one of its official languages, Tetum (lorosa' $)^{1}$; and the home, which as well as being very symbolic is also perceived as an uma lulik (sacred house), having the ability to gather the whole community together, and is a strong identity marker in the various communities. The mixture between the animistic original culture and the religious thinking, as a result of the colonization and the Christianization process, is also present in these identity symbols, which were sometimes reinterpreted by the Catholic Church and incorporated in the local culture.

Margaret Meek reinforces this by stating that "local cultures are the strongest social bonds. (...) Language is an obvious cohesive factor everywhere" (Meek 2001: xi). The values which are intrinsically linked to Timorese identity are related to the spirit of resistance, closely associated with suffering and the desire for freedom and independence, as well as with armed combat and the fight between the occupants and the occupiers, a sort of utopia which both unites and differentiates. The various wars which took place in the country, and particularly the resistance's fight for independence and autonomy during the 24 years of occupation, are other factors which ensure the stability of the identity of the people and which are present in official symbols and in political and civilian discourse and actions.

\section{Corpus Analysis}

East Timor contemporary history isn't a common theme in Portuguese children's literature. In fact, only two picturebooks were written in the last years about this country, depicting not only its hard struggle for independence, but also the last years of reconstruction and normalization of the institutions and routines. We intend to analyse how these two picturebooks express, in text and pictures, East Timor identity in order to communicate it to both Portuguese and East-Timorese young readers, offering a different approach to challenging themes.

\section{Timor Lorosa'e. A Ilha do Sol Nascente (2001)}

[East Timor - Island of the Rising Sun], text by João Pedro Mésseder and illustrations by André Letria

Timor Lorosa'e. A Ilha do Sol Nascente (Timor Lorosa'e. Land of the Rising Sun) was published in 2001 and written during the events which prompted the intervention of the UN, with the death of many people and the destruction of all the country's infrastructures. It is interventional in nature and defends the independence of East Timor and its right to self-government. The motivation behind the development of the book is connected to the political and civic actions of its creators, who like many others also took part in the demonstrations against Indonesian occupation. The book was, according to the author's personal accounts, a result of various conversations between its creators, who discussed

1 The name of East Timor in Tetum is Timor Lorosa'e, which means Timor, Rising Sun. 
the structure of the book, its format and layout, as well as the symbolic meaning behind the colours and shapes used, namely the circle, and the concepts which underpin the book, making it a clear example co-authorship and collaboration.

In much the same way as Beauvais' study (2013) revealed the revolution as being a strong factor in the construction of French identity, the war for independence also becomes a feature which ensures the existence of the territory as an autonomous and selfgoverning country: "Nation-building, going from repression to emergence, is naturalised, the child invited to envisage her growth and maturation in parallel with the development of the nation on its way to freedom" (Beauvais 2013: 116). The war and other conflicts are literally recreated in this picturebook as elements which help to construct identity, and unmistakeably belong to the world of children's literature in that they clearly and unequivocally present the juxtaposition between "us" and "them" (Meek 2001: ix) from a very patriotic perspective.

The book is organised in a dichotomous way and establishes a clear difference between two peoples, the Timorese, who are the natives of the island, and the invaders, who are the aggressive occupants of the territory. The definition of both communities is very relevant from an identity point of view, and specific Timorese characteristics connected to serenity and wisdom and the desire for independence are reinforced through the identification of the differences between the two peoples ("and where a small, serene and wise people / one day wanted to build a country" - my translation). In clear opposition to this, polysyndeton is used to represent the invaders as "foreigners" and "serving powerful leaders" (my translation) by taking on certain behaviours and actions that move gradually from occupation to theft, from death to massacre. "And once again they burnt / and killed and massacred" (my translation). This opposition reinforces national identity (Meek 2001), which has to be attained through struggle and the collaboration of external peacekeeping forces, which bring an end to the suffering of the small community. The adjective "small" brings to the fore another important factor of national Timorese identity, the ability to resist in the face of adversity and a clearly superior enemy. The frequent use of expressive adjectives, metaphors and comparison, polysyndeton and at times anaphora, are used together to build a text which uses the hope for independence and freedom, and more importantly reconstruction, to create a happy ending.

From a symbolic point of view, the iconotext is very strong and expressive, often allowing metaphoric interpretations of the most important events, which the readers may or may not know about, recreated in a fantastic or almost fable-like manner. Text and images identify features of Timorese identity, with reference to "the green island in the shape of a crocodile", "the rising sun" and "Mother Nature's mountains", visually recreating the landscape, the sun, the mountains and the traditional sacred houses (fig. 1).

The dichotomy between Good and Bad is also explicit in the two discourses used in the picturebook. The actions of the invaders correspond to the period of darkness: "a night which seemed long, as long as death itself" (my translation) and associated with massacre and genocide, ethically justifying the war for independence in the struggle to free the weak 


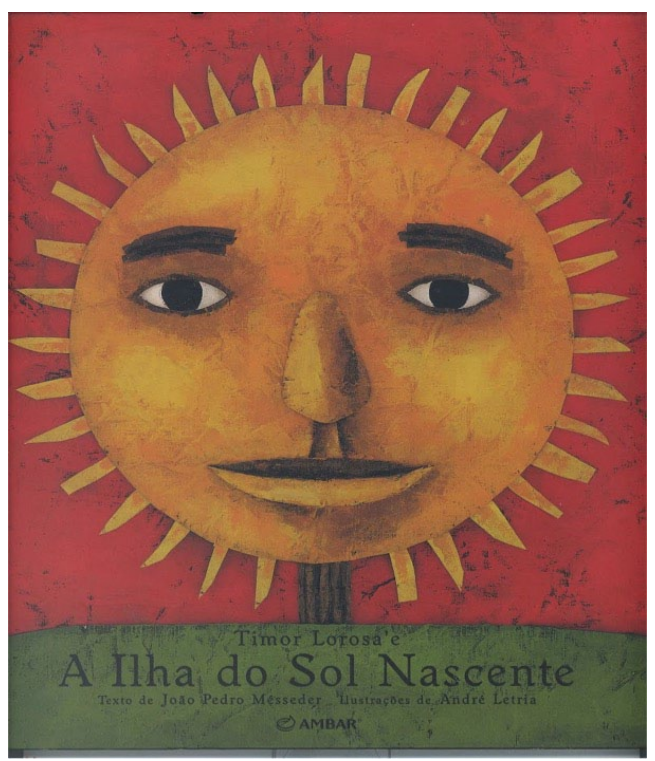

Fig. 1. Picturebook cover

and oppressed. The ousting of the invading soldiers by the freedom fighters results in the slow and progressive return to the light after years of darkness. To represent this, the use of antonymic concepts is clear both from a chromatic and an illustrative point of view, with the shadows, night and death portrayed during the period of invasion and occupation and the dawn, light and the (sun)rise of liberty metaphorically connected to freedom and selfgovernment, all of which clearly overlap with national Timorese identity.

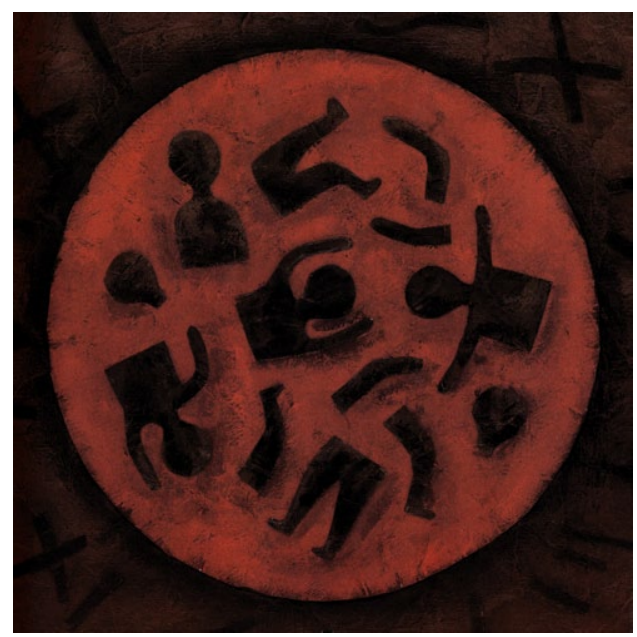

Fig. 2. Picturebook illustration 
Taking centre-stage on all the odd-numbered pages, the illustrations stand out not only due to the scale of the book but also in stark comparison with the even-numbered pages, which have a white background and where the text is more peripheral. In this way, and in view of the violence of the facts which make up the story, the narrator does not play down the occupation, the suffering and the death, and the white space is used to highlight the dramatic impact of the lack of visual and textual input. The various possible interpretations, which are more factual and historic in nature, are clear, at least to the adult reader, alluding to political ${ }^{2}$ events and facts in a more symbolic and metaphoric way, thus recreating a common desire for freedom and independence of peoples and nations. The references which help to situate the narrative in contemporary history are the name of the country in the title and the date of the arrival of the international troops. All the other references are only alluded to, and it is up to the adult mediator to decide upon factors such as the nationality of the invaders, the referendum of 1999, the intervention of the UN and the characterisation of the "men who rule the world" as Americans ("- some men who rule the world and give orders to generals finally decided to send soldiers to the land of the rising sun." - my translation).

Poetic and metaphoric, but also realistic and factual, this picturebook combines a very concise text with very large illustrations, which increase the reading possibilities of this volume, selected for the White Ravens List in 2003 for its particular qualities.

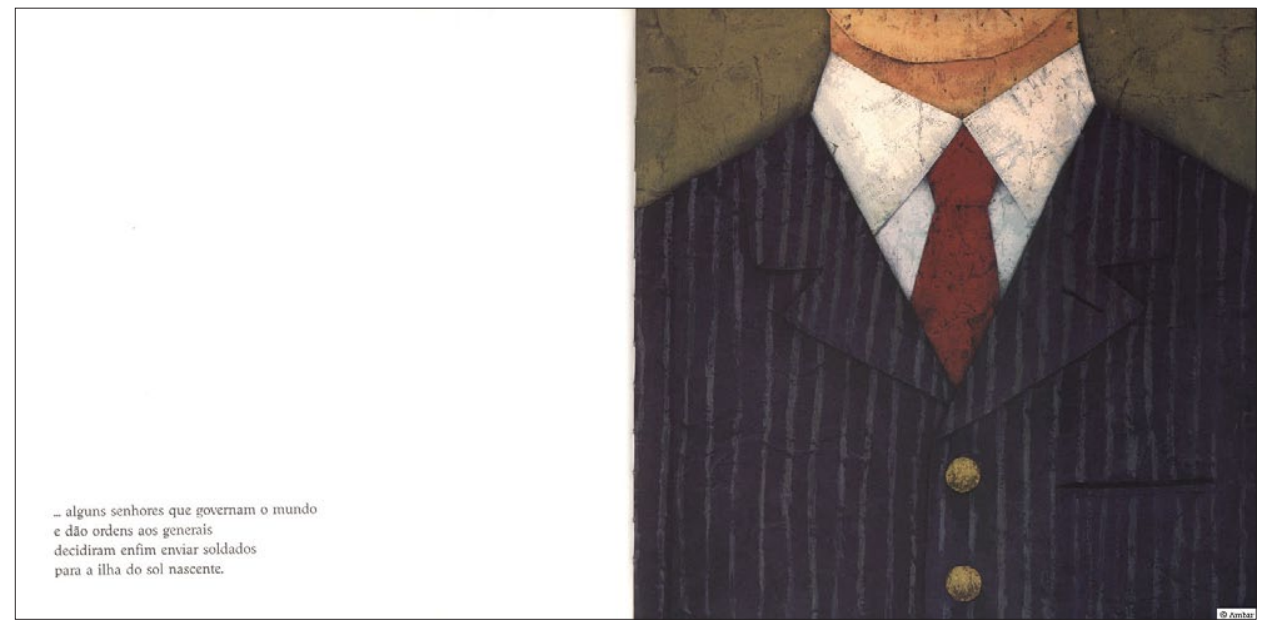

Fig. 3. Picturebook double spread

\footnotetext{
2 To read more about the political nature of the issue in Portuguese children's literature and literature for young adults, see Balça 2008.
} 


\section{Lya/Lia (2014), text and illustrations by Margarida Botelho}

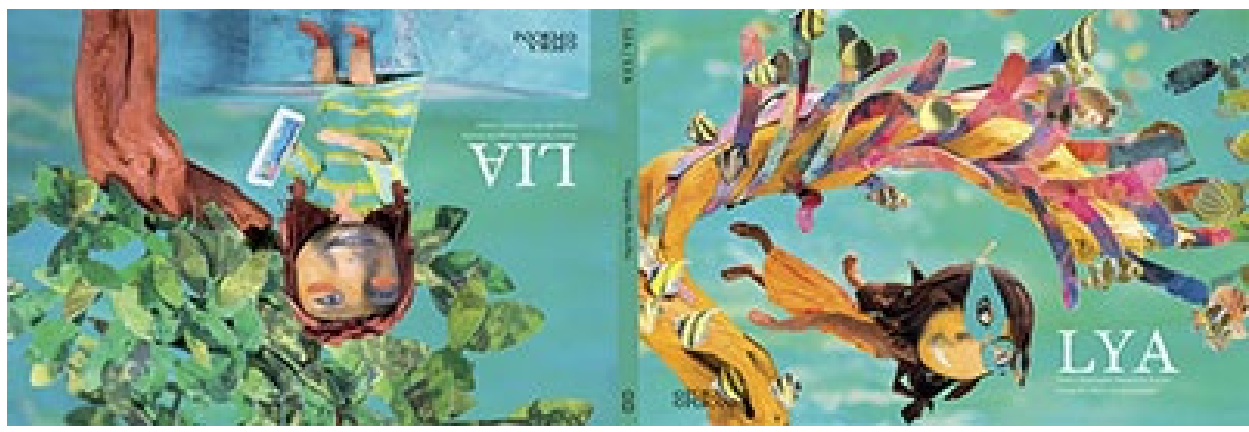

Fig. 4. Picturebook cover

Lya/Lia includes two narratives which can be read in two directions, which clearly presents the differences and similarities between Portugal and East Timor, implicitly evoking reflection on the features which identify and differentiate them. The story lines clearly show the differences, in a somewhat stereotypical ${ }^{3}$ way, between a rural and urban environment, building the daily routine of the two main characters who lend their names to the title of the book. For the objectives of this paper, the main focus is the first text, where the Timorese girl Lya living in a community in the small island of Atauro, is the protagonist. The text is marked by close contact with nature and Lya's daily routine is strongly linked with members of her close and extended family, friends and animals, and portrayed in an altruistic way within the community.

This book is the result of a project undertaken by the author to portray lifestyles in different countries and communities, establishing a parallel with Portuguese settings. The author's first book portrayed Mozambique (Eva, 2011), followed by the Amazon in Brazil (Yara/Iara, 2012) and East Timor (with Lya/Lia, 2014). Besides their narrative structure, the picturebooks focus on faraway communities which have some affinity with Portuguese/Lusophone culture, with an emphasis on rural settings, people's connection to nature and harsh living conditions.

This book is less metaphorical than the previous picturebook, and the realism of the actions, characters and scenes is more faithful to the community in which the author lived temporarily. In this way, the features which are present in the picturebook and which mark identity besides tetum, the official language of East Timor, the sacred home, a symbol of community, the memory of the struggle for independence and the mountains, which provide refuge for the resistance movement. The legend of the creation of the territory, with a boy and a crocodile, which transforms itself into an island, is also present in the game which unites both narratives in the middle of the book.

3 The issue of stereotypes is discussed by Carol Fox, when she highlights the importance of adult intervention in the reading process, since "National identities are generalisations, and, inevitably, stereotypical characterisations of histories, people and settings. Some children's literature simplifies things, so that children can understand them" (Fox 2001: 50). 


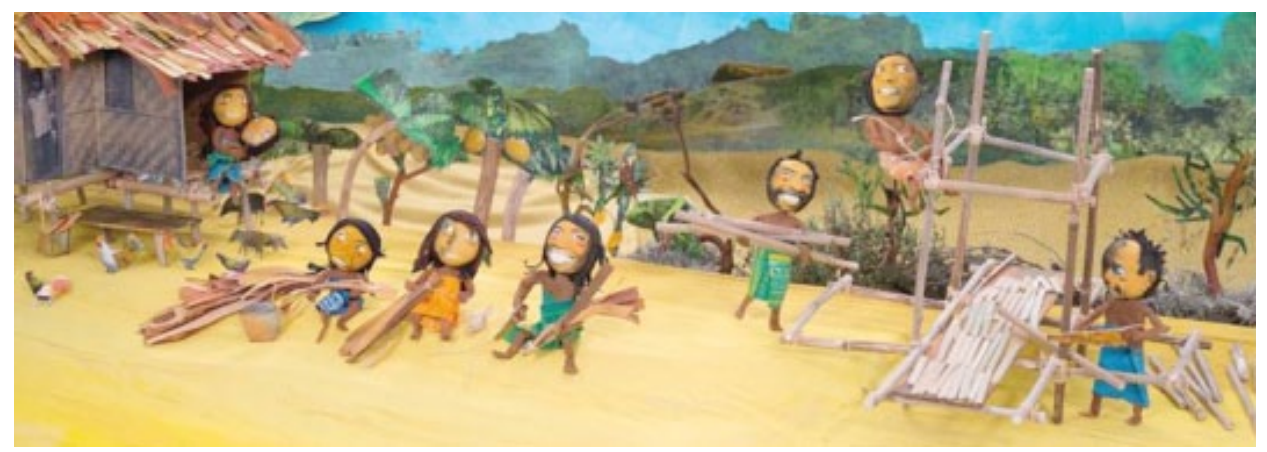

Fig. 5. Picturebook illustration technique

The technique chosen for the illustrations brings together three-dimensional elements using colouring and shading, cut-out and collage, creating scenes where the characters appear to move. These visual images help to create perspective with the use of greater definition and perceptions of depth and movement, as well as careful portrayal of lighting to show the shifting time of day. The use of vibrant colours and cutouts give particular emphasis to the local hues of the landscape, the flora and fauna, the architecture and the clothing and accessories, as well as the facial features of the characters.

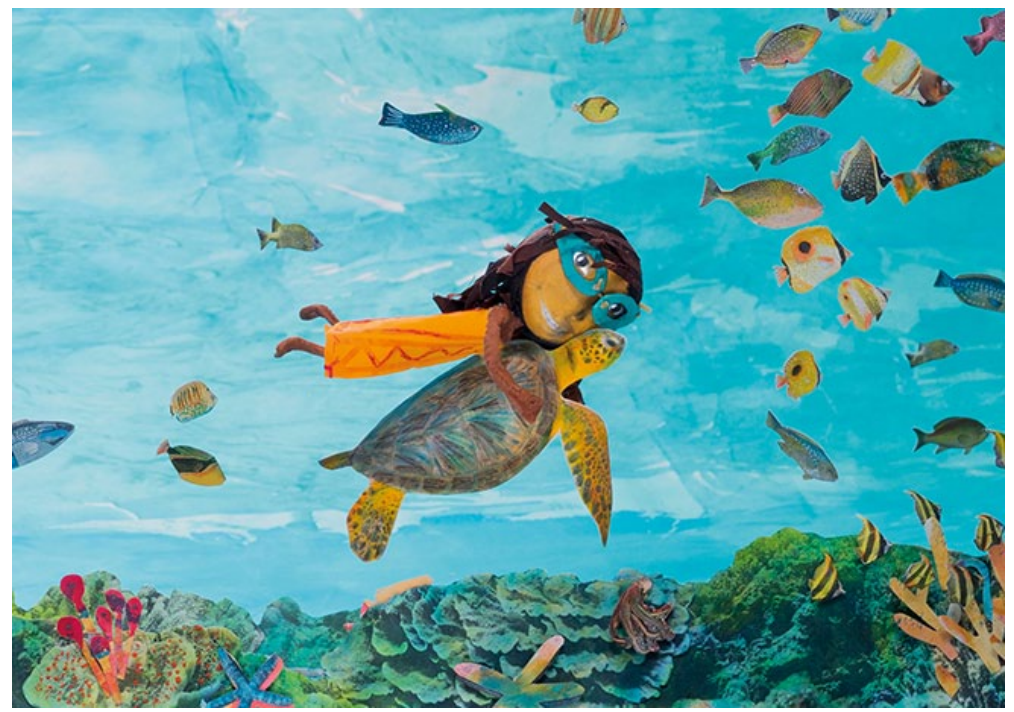

Fig. 6. Picturebook illustration example 


\section{Conclusions}

The two picturebooks analysed in this paper present two distinct visions of East Timor, separated by 13 years, and conceptualised from a Portuguese observational/targeted point of view and within the scope of recent Portuguese history. The first volume is clearly marked by the process of Indonesian occupation and the violence that occurred during their exit. The second book is more contemporary, recreating a context of peace and stability under a democratic regime of self-government and independence against the backdrop of the grandfather's memories of a past of suffering and plight, which has become a motive for celebration and a national holiday.

The interventional nature of the first book is mitigated in the second due to the fact that it has as its main objectives the dissemination of information and is more ludic in nature. It is possible to see that the development of the theme in these picturebooks and the values they defend are in line with the social and political backdrop which contextualises the narratives, spanning from the struggle for independence, freedom and peace to defending such values as education and accompanying the development of this young nation. Although to different effects and in very different contexts, both picturebooks contribute towards the construction of a national Timorese identity by differentiating it from Indonesian culture in the first book and Portuguese culture in the second.

In both books, the illustrations are particularly noteworthy, with features which are highly original, including a similar chromatic effect which takes full advantage of the variations in colour and hue. The structure of the picturebooks also deviates from the norm and the book by Margarida Botelho has two narratives which can be read in both directions and which meet in the middle, reinforcing the idea of intercultural dialogue through the establishment of points of juncture and differences between Portuguese and Timorese culture. The use of comparison, words in Tetum and the presentation of specific social and cultural practices bring readers, particularly Portuguese readers, closer to Timorese traditions, increasing their curiosity of another culture and highlighting the major differences in both lifestyles, although still centred on common values such as the home, family, school, friends, play and games.

Knowing that the country has yet to find an autonomous and authentic voice which is able to express the hopes and fears of the Timorese community in literary texts aimed at younger readers, these Portuguese authors appear to use their voices to express the identity of a recent country with age-old traditions.

In this way, the project of (re)building the Timorese culture is carried out by "foreign" authors who seek to identify the most relevant and specific aspects of national/local culture and disassociate them from the occupying power or colonising country. The landscape, flora and fauna, the cultural practices and routines, the architecture, the clothing and the language are some of the features of identity that the texts and illustrations highlight. Nature and culture are valued as elements which help to construct identity, reinforce common and identifiable values and have the ability to unite a people and disassociate them 
from the others, namely the invaders/occupiers: "Nations at war and nations seeking Independence often have a strong need to build or rebuild their national identity, including in cultural terms" (Ommundsen 2013: 12).

The presence of various features and cultural values associated with Timorese identity, such as the crocodile, the mountains, the rising sun, the values and spirit of the resistance movement and rituals, be it through the texts or the illustrations, works to some extent as an explicit vindication of a national conscience, thus justifying the existence of this new fledgling country from southwest Asia from a political point of view. The development from one picturebook to the other shows the way which has been paved and the notion of nation state consolidated. However, both books still make reference to the struggle of the resistance to defend the country and claim freedom and democracy.

The two picturebooks analysed in this paper, which are true iconotexts (combining perfectly text and image), portray the events leading up to and after the independence of the country and this decisive moment in the construction of a national Timorese identity. They focus on the chronotope of independence, desired or achieved. The picturebooks also recreate a mythical, idealised place and time, manifold possibilities by portraying a pivotal moment in Timorese history shared by all.

\section{References}

\section{Corpus}

Mésseder J.P. (2001), Timor Lorosa'e. A Ilha do Sol Nascente. Lisbon, Caminho (illustrated by André Letria).

Botelho M. (2014), Lya/Lia, no location, vanity press.

\section{Works of reference}

Agnew J. (1998), Introduction: European Landscape and Identity. In: B. Graham (ed.), Modern Europe: Place, Culture and Identity. London, Arnold.

Balça Â. (2008), Literatura Infantil Portuguesa - de temas emergentes a temas consolidados. "RevistaEf@bulações”, 2.

Beauvais C. (2013), "It's forbidden to forbid": Constructions of Frenchness through Revolution in Three Contemporary Picturebooks. In: A.M. Ommundsen (ed.), Looking Out and Looking In. National Identity in Picturebooks of the New Millenium. Oslo, Novus AS.

Desai C.M. (2006), National Identity in a Multicultural Society: Malaysian Children's Literature in English. "Children's Literature in Education", 37.

Fox C. (2001), Conflicting Fictions: national identity in English children's literature about war. In: M. Meek (ed.), National Identity and Children's Literature. London, Trentham Books.

Meek M. (Ed.) (2001), National Identity and Children's Literature. London, Trentham Books.

Ommundsen A.M. (ed.) (2013), Looking Out and Looking In. National Identity in Picturebooks of the New Millenium. Oslo, Novus AS.

Stephens J. (1992), Language and Ideology in Children's fiction. New York, Longman Publishing. 